\title{
PENGARUH PEMBERIAN BAHAN HUMAT DARI EKSTRAK BATUBARA MUDA (Subbituminus) DAN PUPUK P TERHADAP SIFAT KIMIA ULTISOL SERTA PRODUKSI TANAMAN JAGUNG (Zea mays L.)
}

\author{
Herviyanti, Fachri Ahmad ${ }^{1}$, Riza Sofyani, Darmawan ${ }^{1}$, Gusnidar ${ }^{1}$, dan Amrizal Saidi ${ }^{1}$ \\ D osen J urusan Tanah, F akultas Pertanian, U niversitas Andalas Limau M anis, Padang 25163, \\ herviyanti64@yahoo.com
}

\begin{abstract}
The purpose of this research is to study interaction of humic substances extracted from subbituminus coal with $\mathrm{P}$ fertilizer on the chemical properties of Ultisol and crop production of corn (Zea mays L.). The experiment was designed in completely randomized design having 2 factors $(4 \times 4)$ with 3 replications. The first factor was dose of humic substances (A) which consists of 4 levels $\left(A_{1}=0 \mathrm{ppm}, \mathrm{A}_{2}=400 \mathrm{ppm}, \mathrm{A}_{3}=800 \mathrm{ppm}\right.$, and $\left.\mathrm{A}_{4}=1200 \mathrm{ppm}\right)$. The second factor was level of fertilizer $\mathrm{P}(\mathrm{B})\left(\mathrm{B}_{1}=100 \%\right.$ recommendation, $\mathrm{B}_{2}=75 \%$ recommendation, $\mathrm{B}_{3}=50 \%$ recommendation, and $\mathrm{B}_{4}=25 \%$ ). The result showed that : 1 ) There is no interaction between humic substances and $\mathrm{P}$ fertilizer on the chemical nature of Ultisol and crop production of corn (Zea mays L.) 2) Use of humic substance for $800 \mathrm{ppm}$ with some level of $\mathrm{P}$ fertilizer could improve some chemical properties of Ultisol such as decreased in content of Al-exch by $0,38 \mathrm{me} / 100 \mathrm{~g}$ soil, increased in P-available by $22,16 \mathrm{ppm}$, CEC by $8,42 \mathrm{me} / 100 \mathrm{~g}$ soil and $\mathrm{P}$ nutrient by $0,10 \%$, as well as corn yield by $25,67 \mathrm{~g} / \mathrm{pot}$ compared to soil without humic substances 3) The use of SP-36 for $50 \%$ with some level of humic substances increased in plant height by $26,58 \mathrm{~cm}, \mathrm{P}$ nutrient by $0,11 \%$, and the use of $75 \%$ SP-36 increased corn yield by 5,84 g/pot compared to $25 \%$ of P recommended.
\end{abstract}

Keywords : humic subtances, subbituminus coal, P fertilizer.

\section{PENDAHULUAN}

Tanah-tanah yang tersedia untuk pertanian sekarang dan akan datang adalah tanah-tanah bereaksi masam $(\mathrm{pH}$ rendah) dan miskin unsur hara, seperti ordo Ultisol. Ditinjau dari sudut luasnya, Ultisol mempunyai potensi yang besar untuk dijadikan lahan pertanian. Luas Ultisol di Indonesia mencapai 45,8 juta ha atau $25 \%$ luas tanah Indonesia (Subagyo et al., 2004). Oleh karena itu, pengelolaan kesuburan tanah masam seperti Ultisol perlu mendapat perhatian.

Permasalahan utama yang dihadapi pada Ultisol jika dijadikan lahan pertanian adalah keracunan aluminium (Al) dan besi $(\mathrm{Fe})$ serta kekurangan hara terutama fosfor (P). Unsur $\mathrm{Al}$ dan $\mathrm{Fe}$ yang banyak larut pada tanah masam akan mudah mengikat $\mathrm{P}$, sehingga penambahan pupuk $\mathrm{P}$ kurang bermanfaat bagi tanaman dan efisiensi pemupukan $\mathrm{P}$ menjadi rendah. Salah satu upaya yang dapat dilakukan untuk mengatasi masalah tersebut adalah dengan penambahan bahan organik. Bahan organik dalam proses dekomposisinya akan melepaskan asam-asam organic yang dapat mengikat $\mathrm{Al}$ dan $\mathrm{Fe}$ membentuk senyawa kompleks atau khelat, sehingga $\mathrm{Al}$ dan $\mathrm{Fe}$ menjadi tidak larut. Pemberian bahan organik dalam bentuk bahan humat ke dalam tanah merupakan salah satu upaya untuk mempercepat proses ameliorasi tanah terutama Ultisol, karena bahan humat merupakan komponen bahan organik yang paling reaktif di dalam tanah. (Tan, 2010).

Bahan humat dapat diperoleh dari berbagai jenis bahan organik terutama dari yang telah terdekomposisi sempurna seperti pupuk kandang, kompos sampah kota, kompos jerami padi, dan tanah gambut, tetapi kadar dari bahan humat yang diperoleh sedikit sekali yaitu $<10 \%$. Herviyanti (2007), menjelaskan bahwa asam humat dari pupuk kandang hanya $1,5 \%$, 
kompos sampah kota 1,4\%, kompos jerami padi $5 \%$ dan dari tanah gambut $9,2 \%$. Untuk itu perlu dicari alternatif memperoleh bahan humat yang lebih tinggi. Hasil penelitian Rezki (2007), memperoleh 31,5 $\%$ bahan humat dari batubara muda (Subbituminus) Kabupaten Pasaman dan $15,4 \%$ bahan humat dari batubara muda (Subbituminus) Kota Sawahlunto yang diekstrak dengan 0,5 $\underline{\mathrm{N}} \mathrm{NaOH}$. Oleh karena itu dalam penelitian ini digunakan bahan humat dari batubara muda yang berasal dari Pasaman.

Subbituminus merupakan batubara muda dengan tingkat pembatubaraan rendah yang biasanya lebih lembut dengan materi yang rapuh dan berwarna suram seperti tanah, memiliki kelembaban yang lebih tinggi dan kadar karbon yang lebih rendah, sehingga kandungan energinya juga rendah. Oleh karena itu Subbituminus ini tidak efektif dimanfaatkan sebagai sumber energi dan sebaiknya dimanfaatkan sebagai sumber bahan humat.

Tujuan penelitian ini adalah untuk mengetahui pengaruh interaksi pemberian bahan humat dari ekstrak batubara muda (Subbituminus) dan pupuk $\mathrm{P}$ terhadap sifat kimia Ultisol dan produksi tanaman jagung (Zea mays L.).

\section{METODOLOGI PENELITIAN}

Penelitian ini dilaksanakan pada bulan Agustus 2009 sampai Februari 2010, di Rumah Kaca Laboratorium Jurusan Tanah Fakultas Pertanian Unand. Tanah yang digunakan adalah Ultisol Tanjung Pati, Kabupaten Lima puluh Kota Payakumbuh yang diambil pada kedalaman $0-20 \mathrm{~cm}$ dari permukaan tanah secara komposit. Sampel tanah yang telah diayak dimasukkan kedalam ember plastik masing-masing 8 $\mathrm{kg} /$ pot setara kering mutlak, dengan jumlah pot adalah 48 pot. Sebagai sumber bahan humat digunakan batubara muda yang tidak produktif, dan diekstrak dengan $\mathrm{NaOH} 0,1$ $\mathrm{N}$. Batubara yang digunakan mengandung $31,5 \%$ bahan humat.

Penelitian ini berupa percobaan pot menggunakan Rancangan Acak Lengkap (RAL) dalam bentuk faktorial 4 x 4 dengan
3 ulangan. Faktor pertama adalah takaran bahan humat (A) yang terdiri atas 4 taraf yaitu $A_{1}=0 \mathrm{ppm}, \mathrm{A}_{2}=400 \mathrm{ppm}(0,85 \mathrm{~L}$ $\left.\operatorname{pot}^{-1}\right), \mathrm{A}_{3}=800 \operatorname{ppm}\left(1,73 \mathrm{~L} \mathrm{pot}^{-1}\right), \mathrm{A}_{4}=$ $1200 \mathrm{ppm}\left(2,59 \mathrm{~L} \mathrm{pot}^{-1}\right)$ dan faktor yang kedua adalah takaran SP-36 (B) yang terdiri atas 4 taraf yaitu $\mathrm{B}_{1}=100 \%$ rekomendasi $\left(5,62 \mathrm{~g} \mathrm{pot}^{-1}\right), \mathrm{B}_{2}=75 \%$ rekomendasi $(4,21$ $\left.\mathrm{g} \mathrm{pot}^{-1}\right), \mathrm{B}_{3}=50 \%$ rekomendasi $\left(2,81 \mathrm{~g} \mathrm{pot}^{-}\right.$ $\left.{ }_{1}\right), \mathrm{B}_{4}=25 \%$ rekomendasi $\left(1,40 \mathrm{~g} \mathrm{pot}^{-1}\right)$. Rekomendasi pupuk P adalah $300 \mathrm{~kg} / \mathrm{ha}$ SP36(Sembiring, 1996). Data hasil penelitian dianalisis secara statistik dengan uji $\mathrm{F}$ dan dilanjutkan dengan uji lanjutan DNMRT taraf nyata $5 \%$.

Tanah yang telah dimasukkan kedalam pot, lalu diberi bahan humat dari ekstrak batubara sesuai perlakuan, lalu diaduk hingga rata. Kemudian diinkubasi selama seminggu. Setelah itu dilakukan pemberian SP-36 sesuai perlakuan dan diinkubasi lagi selama satu minggu, lalu dilakukan pengambilan sampel tanah pada masing-masing perlakuan. Pupuk dasar yang diberikan yaitu Urea $300 \mathrm{~kg} / \mathrm{ha}$, dan $\mathrm{KCl} 150 \mathrm{~kg} / \mathrm{ha}$. Pemupukan dilakukan berdasarkan jumlah populasi dengan jarak tanam 75 × $25 \mathrm{~cm}$. Kemudian jagung ditanam sebanyak 3 biji perlubang secara tugal. Pemeliharaan yang dilakukan selam ${ }^{-}$ penelitian meliputi penyiraman, penyiang dari gulma, dan pemberantasan har.... penyakit. Panen dilakukan pada saat tanaman berumur 103 HST dengan tandatanda kelobot sudah berwarna kuning, bijinya sudah cukup keras dan mengkilap, dipangkal biji sudah ada garis hitam dan apabila ditusuk dengan kuku ibu jari maka tidak akan meninggalkan bekas.

Analisis kimia tanah dilakukan sebanyak dua kali, yakni analisis tanah awal dan sesudah inkubasi. Analisis tanah awal meliputi pengukuran $\mathrm{pH} \quad \mathrm{H}_{2} \mathrm{O}$ dengan metode elektrometrik, pengukuran $\mathrm{C}$ organik dengan metoda Walkley and Black, $\mathrm{P}$ tersedia dengan metoda Bray II, $\mathrm{N}$ total dengan metoda Kjeldhal, Kapasitas Tukar Kation (KTK), K-dd, Ca-dd, Mg-dd, Na-dd, Al-dd, dan Fe-dd dengan metode ekstraksi 1 $\underline{\mathrm{N}}$ ammonium asetat $\mathrm{pH} 7$ serta diukur dengan Atomic Absorption Spectrometer (AAS). Analisis kedua dilakukan setelah 
inkubasi dengan bahan humat dan pupuk $\mathrm{P}$, yaitu pH $\mathrm{H}_{2} \mathrm{O}$, KTK, C-Organik, N-Total, dan P-tersedia.

Pengamatan tanaman yang dilakukan adalah tinggi dan kadar hara $\mathrm{P}$ tanaman yang diukur pada saat tanaman berumur 70 hari setelah tanam (HST) yaitu pada saat masa vegetatif maksimum. Analisis kadar P tanaman dilakukan dengan mengambil sampel daun, lalu dimasukkan ke dalam amplop yang telah dilubangi, dikeringkan dalam oven selama 2 x 24 jam pada suhu $65^{\circ} \mathrm{C}$ kemudian digrinder. Bobot biji kering ditimbang setelah dikeringkan dalam oven suhu $65^{\circ} \mathrm{C}$ selama $2 \times 24$ jam, dan dikonversi ke kadar air $14 \%$.

\section{HASIL DAN PEMBAHASAN}

\section{Hasil Analisis Tanah Awal}

Tabel 1 menunjukkan bahwa Ultisol yang digunakan untuk penelitian ini memiliki kesuburan rendah, dimana $\mathrm{pH}$ tanah sangat masam, KTK dan basa-basa berada pada kriteria sangat rendah sampai sedang, kejenuhan $\mathrm{Al}$ dan Fe-dd sangat tinggi. Kondisi tanah ini disebabkan oleh curah hujan yang tinggi menyebabkan basabasa tercuci secara intensif, sehingga kation Al dan $\mathrm{H}$ tinggal sebagai kation dominan yang menyebabkan tanah bereaksi masam. Sumbangan unsur hara pun sangat sedikit karena Ultisol merupakan tanah yang telah mengalami pelapukan intensif.

Kandungan $\mathrm{Fe}$-dd dan kejenuhan $\mathrm{Al}$ sangat tinggi menyebabkan P-tersedia tanah menjadi rendah, karena terfiksasi oleh $\mathrm{Al}$ dan Fe. Makin besar konsentrasi $\mathrm{Al}$ dan $\mathrm{Fe}$ yang larut, makin besar pula jumlah $\mathrm{P}$ yang diikat. Ahmad (1988) dan Hardjowigeno (2003) mengemukakan bahwa, rendahnya ketersediaan P pada Ultisol disebabkan oleh $\mathrm{pH}$ yang bersifat masam dan terjadinya fiksasi $\mathrm{P}$ oleh $\mathrm{Al}$ dan $\mathrm{Fe}$ yang bermuatan positif, sehingga $\mathrm{P}$ sukar tersedia bagi tanaman. C-organik, N-total dan $\mathrm{C} / \mathrm{N}$ yang tergolong rendah karena kandungan bahan organik sangat sedikit sehingga tidak dapat menyumbangkan hara.

Tabel 1. Hasil Analsis Awal Beberapa Sifat Kimia Ultisol Tanjung Pati, Payakumbuh

\begin{tabular}{lll}
\hline Analisis tanah & Nilai & Kriteria \\
\hline pH H2O & 5,37 & Masam* \\
KTK $(\mathrm{me} / 100 \mathrm{~g})$ & 15,00 & Rendah* \\
K-dd $(\mathrm{me} / 100 \mathrm{~g})$ & 0,49 & Sedang* \\
Ca-dd (me/100 g) & 0,28 & Sangat rendah* \\
Mg-dd(me/100 g) & 0,58 & Rendah* \\
Na-dd (me/100 g) & 0,28 & Rendah* \\
Kejenuhan basa (\%) & 10,87 & Sangat rendah* \\
Al-dd(me/100 g) & 2,94 & \\
Kejenuhan Al (\%) & 64,33 & Sangat tinggi* \\
Fe-dd (ppm) & 246,40 & Sangat tinggi*** \\
P- Tersedia & 11,76 & Rendah** \\
C-Organik $(\%)$ & 1,19 & Rendah* \\
N-Total $(\%)$ & 0,19 & Rendah* \\
C/N & 6,26 & Rendah* \\
\hline
\end{tabular}

Sumber * Staf Pusat Penelitan Tanah (1983 ; cit Hardjowigeno,2003)

**Team Architects and Consulting Enginering bekerjasama denga Fakultas Pertanian Universitas Andalas (1981)

*** Lembaga Penelitian Tanah (LPT) Bogor cit Sarief (1986) 
Untuk menghasilkan pertumbuhan tanaman yang baik diperlukan perbaikan kondisi kesuburan tanah terlebih dahulu. Salah satu upaya yang dapat dilakukan adalah dengan penambahan bahan humat kedalam tanah.

\section{Analisis Tanah setelah Inkubasi}

\section{1. $\mathrm{pH}$ dan Al-dd tanah}

Pengaruh pemberian bahan humat pada berbagai takaran pupuk $\mathrm{P}$ terhadap $\mathrm{pH}$ dan Al-dd Ultisol disajikan pada Tabel 2 dan 3. Pengaruh interaksi pemberian bahan humat dan pupuk $\mathrm{P}$ tidak berbeda nyata, namun faktor pemberian bahan humat berbeda nyata terhadap nilai $\mathrm{pH} \mathrm{H}_{2} \mathrm{O}$ dan Al-dd tanah. Pada takaran bahan humat 800 dan $1200 \mathrm{ppm}$ terjadi peningkatan $\mathrm{pH}$ tanah masing-masing sebesar 0,12 dan 0,15 unit dan penurunan Al-dd sebesar 0,38 dan 0,62 me/100 g dibanding tanpa bahan humat.

Bahan humat merupakan hasil akhir dekomposisi bahan organik, peningkatan $\mathrm{pH}$ tanah dan penurunan Al-dd tanah akibat pemberian bahan humat disebabkan oleh muatan negatif dan gugus fungsional bahan humat (gugus karboksil $\left(\mathrm{COO}^{-}\right)$dan fenolat $\left(\mathrm{OH}^{-}\right)$] membentuk senyawa kompleks atau khelat dengan $\mathrm{Al}$, sehingga kelarutan $\mathrm{Al}$ di dalam tanah berkurang dan kemungkinan untuk terjadinya hidrolisis Al berkurang juga berkurang. Menurut Huang dan Schnitzer (1997) dengan peningkatan takaran asam humat maka terjadi pula peningkatan gugus fungsional asam humat, sehingga dapat membentuk kompleks melalui gugus fungsional $(-\mathrm{COOH})$ dan phenolic (-OH) dengan $\mathrm{Al}^{3+}$ dalam jumlah yang cukup banyak. Akibatnya $\mathrm{Al}^{3+}$ yang dapat dipertukarkan menjadi berkurang. Tan (2010) menyatakan bahwa Al yang terjerap oleh komplek liat dapat terhidrolisis dan menghasilkan ion $\mathrm{H}^{+}$, sehingga konsentrasi ion tersebut meningkat di dalam tanah. Dengan terbentuknya komplek antara Al dengan asam organik maka reaksi hidrolisis Al dapat dihalangi. Selanjutnya Rezki (2009) pada Oxisol

Tabel 2. Pengaruh utama pemberian bahan humat dari ekstrak batubara muda (Subbituminus) dan pupuk $\mathrm{P}$ terhadap $\mathrm{pH} \mathrm{H}_{2} \mathrm{O}$

\begin{tabular}{|c|c|c|c|c|c|}
\hline \multirow{2}{*}{$\begin{array}{l}\text { Takaran Bahan } \\
\text { Humat (ppm) }\end{array}$} & \multicolumn{4}{|c|}{ Takaran Pupuk P (\% Rekomendasi) } & \multirow[t]{2}{*}{ Rata- rata } \\
\hline & 25 & 50 & 75 & 100 & \\
\hline 0 & 5,93 & 5,97 & 5,98 & 5,98 & $5,97 \mathrm{~B}$ \\
\hline 400 & 6,01 & 6,03 & 6,03 & 6,06 & $6,03 \mathrm{AB}$ \\
\hline 800 & 6,02 & 6,08 & 6,10 & 6,14 & $6,09 \mathrm{~A}$ \\
\hline 1200 & 6,10 & 6,11 & 6,13 & 6,15 & $6,12 \mathrm{~A}$ \\
\hline Rata-rata & $6,01 \mathrm{a}$ & $6,05 \mathrm{a}$ & $6,06 \mathrm{a}$ & $6,08 \mathrm{a}$ & \\
\hline $\mathrm{KK}=2,00 \%$ & & & & & \\
\hline
\end{tabular}

Tabel 3. Pengaruh utama pemberian bahan humat dari ekstrak batubara muda (Subbituminus) dan pupuk $\mathrm{P}$ terhadap Al-dd

\begin{tabular}{|c|c|c|c|c|c|}
\hline \multirow{2}{*}{$\begin{array}{c}\text { Takaran Bahan } \\
\text { Humat (ppm) }\end{array}$} & \multicolumn{4}{|c|}{ Takaran Pupuk P (\% Rekomendasi) } & \multirow[t]{2}{*}{ Rata- rata } \\
\hline & 25 & 50 & 75 & 100 & \\
\hline \multicolumn{6}{|c|}{$. \mathrm{me} / 100 \mathrm{~g}$} \\
\hline 0 & 2,15 & 2,06 & 2,00 & 1,95 & $2,04 \mathrm{~A}$ \\
\hline 400 & 1,92 & 1,89 & 1,86 & 1,85 & $1,88 \mathrm{~B}$ \\
\hline 800 & 1,77 & 1,67 & 1,64 & 1,57 & $1,66 \mathrm{C}$ \\
\hline 1200 & 1,57 & 1,54 & 1,35 & 1,25 & $1,42 \mathrm{D}$ \\
\hline Rata-rata & $1,85 \mathrm{a}$ & $1,79 \mathrm{a}$ & $1,71 \mathrm{a}$ & $1,65 \mathrm{a}$ & \\
\hline $\mathrm{KK}=10,53 \%$ & & & & & \\
\hline
\end{tabular}

Angka-angka yang diikuti huruf kecil yang sama pada baris dan huruf besar yang sama pada kolom berbeda tidak nyata menurut uji lanjut DNMRT pada taraf $5 \%$ 
menunjukkan bahwa penggunaan asam humat dari batubara muda (Subbituminus) dapat meningkatkan nilai $\mathrm{pH}$ dari sangat masam $(3,68)$ menjadi masam $(5,13)$ pada dosis $2 \%$ C-organik.

\subsection{Kandungan P-tersedia}

Interaksi antara pemberian bahan humat dan pupuk $\mathrm{P}$ tidak memberikan pengaruh yang nyata, sedangkan pengaruh utama bahan humat dan takaran pupuk $\mathrm{P}$ nyata terhadap kandungan P-tersedia tanah seperti disajikan pada Tabel 4. Pemberian bahan humat takaran 400 ppm dapat meningkatkan P-tersedia tanah sebesar 10,67 ppm dibandingkan tanpa bahan humat. Kandungan $\mathrm{P}$ tanah meningkat seiring dengan peningkatan takaran bahan humat yang diberikan. Pemberian pupuk P 50 dan $75 \%$ dapat meningkatkan kandungan Ptersedia tanah masing-masing sebesar 2,51 dan 3,41 ppm dibanding takaran pupuk P 25 $\%$ rekomendasi. Peningkatan tertinggi terjadi pada takaran pupuk P $100 \%$ yaitu sebesar 5,44 ppm.

Bahan humat berperan dalam meningkatkan ketersediaan $\mathrm{P}$ yaitu dengan mencegah terjadinya interaksi logam $\mathrm{Al}$ dan $\mathrm{Fe}$ dengan ion $\mathrm{P}$ melalui reaksi kompleks dan khelat sehingga $\mathrm{P}$ yang ada di dalam tanah dilepaskan dan pada waktu penambahan pupuk, unsur $\mathrm{P}$ sudah tidak difiksasi oleh $\mathrm{Al}$ dan $\mathrm{Fe}$ kemudian dapat larut, dan tersedia bagi tanaman. Menurut Tan (2010), asam humat dan asam fulvat dapat meningkatkan pembebasan dan daya larut $\mathrm{P}$ anorganik yang tidak larut melalui proses pengkhelatan.

\subsection{Nilai KTK}

Pengaruh pemberian bahan humat dan pupuk P terhadap nilai KTK Ultisol disajikan pada Tabel 5. Dari Tabel 5 terlihat bahwa tidak adanya interaksi antara pemberian bahan humat dan pupuk $\mathrm{P}$, sedangkan faktor utama masing-masing perlakuan memperlihatkan pengaruh

Tabel 4. Pengaruh utama pemberian bahan humat dari ekstrak batubara muda (Subbituminus) dan pupuk P terhadap P-tersedia

\begin{tabular}{|c|c|c|c|c|c|}
\hline \multirow{2}{*}{$\begin{array}{c}\text { Takaran Bahan } \\
\text { Humat (ppm) }\end{array}$} & \multicolumn{4}{|c|}{ Takaran Pupuk P (\% Rekomendasi) } & \multirow[t]{2}{*}{ Rata- rata } \\
\hline & 25 & 50 & 75 & 100 & \\
\hline \multicolumn{6}{|c|}{ ppm. } \\
\hline 0 & 14,03 & 14,54 & 14,60 & 14,90 & $14,52 \mathrm{D}$ \\
\hline 400 & 21,63 & 24,45 & 25,00 & 29,67 & $25,19 \mathrm{C}$ \\
\hline 800 & 33,22 & 35,80 & 37,78 & 39,92 & $36,68 \mathrm{~B}$ \\
\hline 1200 & 40,89 & 45,00 & 46,12 & 47,08 & $44,77 \mathrm{~A}$ \\
\hline Rata-rata & $27,45 \mathrm{c}$ & $29,95 \mathrm{~b}$ & $30,87 \mathrm{~b}$ & $32,89 \mathrm{a}$ & \\
\hline $\mathrm{KK}=7,59 \%$ & & & & & \\
\hline
\end{tabular}

Angka-angka yang diikuti huruf kecil yang sama pada baris dan huruf besar yang sama pada kolom berbeda tidak nyata menurut uji lanjut DNMRT pada taraf $5 \%$

Tabel 5. Pengaruh utama pemberian bahan humat dari ekstrak batubara muda (Subbituminus) dan pupuk P terhadap KTK

\begin{tabular}{|c|c|c|c|c|c|}
\hline \multirow{2}{*}{$\begin{array}{c}\text { Takaran Bahan } \\
\text { Humat (ppm) }\end{array}$} & \multicolumn{4}{|c|}{ Takaran Pupuk P (\% Rekomendasi) } & \multirow[t]{2}{*}{ Rata- rata } \\
\hline & 25 & & 75 & 100 & \\
\hline & \multicolumn{4}{|c|}{$. \mathrm{me} / 100 \mathrm{~g}}$. & \\
\hline 0 & 15,07 & 15,45 & 15,45 & 15,63 & $15,40 \mathrm{D}$ \\
\hline 400 & 21,85 & 22,23 & 22,23 & 22,60 & $22,23 \mathrm{C}$ \\
\hline 800 & 22,98 & 23,73 & 24,07 & 24,48 & $23,82 \mathrm{~B}$ \\
\hline 1200 & 25,05 & 25,24 & 25,43 & 25,62 & $25,33 \mathrm{~A}$ \\
\hline Rata-rata & $21,24 \mathrm{a}$ & $21,66 \mathrm{a}$ & $21,79 \mathrm{a}$ & $22,08 \mathrm{a}$ & \\
\hline
\end{tabular}

$\mathrm{KK}=6,12 \%$

Angka-angka yang diikuti huruf kecil yang sama pada baris dan huruf besar yang sama pada kolom berbeda tidak nyata menurut uji lanjut DNMRT pada taraf $5 \%$ 
yang nyata terhadap nilai KTK Ultisol. Semakin tinggi takaran bahan humat yang diberikan semakin tinggi pula KTK tanah. Pemberian bahan humat takaran 400, 800 dan 1200 ppm meningkatkan KTK tanah masing-masing sebesar 6,83; 8,42 dan 9,93 $\mathrm{me} / 100 \mathrm{~g}$.

Pemberian bahan humat akan menyebabkan jumlah gugus fungsional seperti karboksil - $\mathrm{COOH}$ dan phenolic $-\mathrm{OH}$ meningkat, sehingga sumber muatan negatif akan meningkat pula. Artinya peningkatan jumlah muatan negatif pada koloid tanah menyebabkan KTK tanah akan meningkat pula. Hal ini didukung oleh pernyataan Stevenson (1994), bahwa asam humat memiliki KTK 300-1400 me/100 g, sehingga melalui pemberian bahan humat dapat meningkatkan kemampuan tanah dalam menjerap dan mempertukarkan kation.

\subsection{Kandungan $\mathrm{C}$-organik}

Pemberian bahan humat 400, 800 dan 1200 ppm dapat meningkatkan kandungan C-organik tanah masing-masing sebesar $0,75 \%, 0,99 \%, 1,89 \%$ dibanding tanpa bahan humat. Peningkatan C-organik ini dipengaruhi oleh tingginya konsentrasi C-organik pada batubara yang diekstrak menjadi bahan humat yang ditambahkan ke dalam tanah yaitu sebesar 22,26 \%. Fraksi humat yang berupa asam humat biasanya kaya akan karbon yang berkisar antara $41 \%$ dan $57 \%$ (Tan, 2010). Huang and Schnitzer (1997) menyatakan bahwa asam humat sebagai komponen dari bahan humat mengandung unsur $\mathrm{C} 56,2 \%, \mathrm{O}_{2} 35,5 \%, \mathrm{~N}$
$3,2 \%, \mathrm{H} 4,7 \%, \mathrm{~S} 0,8 \%$ dan asam fulvat mengandung unsur $\mathrm{C} 45,7 \%, \mathrm{O}_{2} 44,8 \%, \mathrm{~N}$ $2,1 \%, \mathrm{H} 5,4 \%, \mathrm{~S} 1,9 \%$.

\section{Pengamatan Tanaman}

\subsection{Tinggi dan kadar hara $\mathrm{P}$ Tanaman} Hasil analisis pemberian bahan humat dari ekstrak batubara muda (Subbituminus) dan pupuk $\mathrm{P}$ terhadap tinggi dan kadar $\mathrm{P}$ tanaman yang diuji lanjut dengan DNMRT pada taraf 5\% disajikan pada Tabel 7 dan 8. Pengaruh interaksi pemberian bahan humat dan pupuk $\mathrm{P}$ tidak berbeda nyata, sedangkan pengaruh takaran bahan humat dan pupuk $\mathrm{P}$ nyata terhadap tinggi dan kadar $\mathrm{P}$ tanaman.

Pemberian bahan humat $400 \mathrm{ppm}$ pada berbagai takaran pupuk $\mathrm{P}$ dapat meningkatkan tinggi tanaman dari 166,08 $\mathrm{cm}$ menjadi 196,00 cm. Sedangkan pemberian bahan humat 800 dan 1200 ppm memperlihatkan tinggi tanaman yang hampir sama dengan perlakuan bahan humat 400 ppm. Pemberian bahan humat 800 ppm dapat meningkatkan kadar $\mathrm{P}$ tanaman sebesar $0,10 \%$ dibanding tanpa pemberian bahan humat.

Pemberian pupuk P 50\% juga dapat meningkatkan tinggi tanaman dari 164,38 $\mathrm{cm}$ menjadi 190,96 cm dibanding pemberian pupuk P 25\%. Pemberian pupuk $\mathrm{P} \quad 75 \%$ dan $100 \%$ rekomendasi memperlihatkan tinggi tanaman yang hampir sama dengan perlakuan $50 \%$. Sedangkan pemberian pupuk P $50 \%$ dan 75 $\%$ meningkatkan kadar $\mathrm{P}$ tanaman sebesar $0,11 \%$ dan $0,14 \%$ dibanding takaran pupuk

Tabel 6. Pengaruh utama pemberian bahan humat dari ekstrak batubara muda (Subbituminus) dan pupuk P terhadap C-organik

\begin{tabular}{|c|c|c|c|c|c|}
\hline \multirow{2}{*}{$\begin{array}{c}\text { Takaran Bahan } \\
\text { Humat (ppm) }\end{array}$} & \multicolumn{4}{|c|}{ Takaran Pupuk P (\% Rekomendasi) } & \multirow{2}{*}{ Rata-rata } \\
\hline & 25 & 50 & 75 & 100 & \\
\hline & & & & & \\
\hline 0 & 1,31 & 1,37 & 1,48 & 1,55 & $1,43 \mathrm{C}$ \\
\hline 400 & 2,15 & 2,15 & 2,15 & 2,27 & $2,18 \mathrm{~B}$ \\
\hline 800 & 2,27 & 2,40 & 2,50 & 2,52 & $2,42 \mathrm{~B}$ \\
\hline 1200 & 3,17 & 3,18 & 3,41 & 3,54 & $3,32 \mathrm{~A}$ \\
\hline Rata-rata & $2,22 \mathrm{a}$ & $2,27 \mathrm{a}$ & $2,39 \mathrm{a}$ & $2,47 \mathrm{a}$ & \\
\hline
\end{tabular}

$\mathrm{KK}=17,44 \%$

Angka-angka yang diikuti huruf kecil yang sama pada baris dan huruf besar yang sama pada kolom berbeda tidak nyata menurut uji lanjut DNMRT pada taraf $5 \%$ 
Tabel 7. Pengaruh utama pemberian bahan humat dari ekstrak batubara muda (Subbituminus) dan pupuk $\mathrm{P}$ terhadap tinggi tanaman

\begin{tabular}{|c|c|c|c|c|c|}
\hline \multirow{2}{*}{$\begin{array}{c}\text { Takaran Bahan } \\
\text { Humat (ppm) }\end{array}$} & \multicolumn{4}{|c|}{ Takaran Pupuk P (\%Rekomendasi) } & \multirow[t]{2}{*}{ Rata-rata } \\
\hline & 25 & 50 & 75 & 100 & \\
\hline & & .c & & & \\
\hline 0 & 107,67 & 180,83 & 180,67 & 195,17 & $166,08 \mathrm{~B}$ \\
\hline 400 & 176,67 & 190,33 & 208,00 & 209,00 & $196,00 \mathrm{~A}$ \\
\hline 800 & 174,50 & 185,33 & 198,00 & 204,67 & $190,63 \mathrm{~A}$ \\
\hline 1200 & 198,67 & 207,33 & 205,33 & 203,00 & $203,58 \mathrm{~A}$ \\
\hline Rata-rata & $164,38 \mathrm{~b}$ & $190,96 \mathrm{a}$ & $198,00 \mathrm{a}$ & $202,96 \mathrm{a}$ & \\
\hline $\mathrm{K}=11,78 \%$ & & & & & \\
\hline
\end{tabular}

Tabel 8. Pengaruh utama pemberian bahan humat dari ekstrak batubara muda (Subbituminus) dan pupuk $\mathrm{P}$ terhadap kadar hara $\mathrm{P}$

\begin{tabular}{|c|c|c|c|c|c|}
\hline \multirow{2}{*}{$\begin{array}{c}\text { Takaran Bahan } \\
\text { Humat (ppm) }\end{array}$} & \multicolumn{4}{|c|}{ Takaran Pupuk P (\%Rekomendasi) } & \multirow{2}{*}{ Rata-rata } \\
\hline & 25 & 50 & 75 & 100 & \\
\hline & & & & & \\
\hline 0 & 0,11 & 0,20 & 0,25 & 0,25 & $0,20 \mathrm{C}$ \\
\hline 400 & 0,14 & 0,20 & 0,27 & 0,40 & $0,25 \mathrm{BC}$ \\
\hline 800 & 0,16 & 0,27 & 0,29 & 0,49 & $0,30 \mathrm{AB}$ \\
\hline 1200 & 0,17 & 0,37 & 0,35 & 0,54 & $0,36 \mathrm{~A}$ \\
\hline Rata-rata & $0,15 \mathrm{c}$ & $0,26 \mathrm{~b}$ & $0,29 \mathrm{~b}$ & $0,42 \mathrm{a}$ & \\
\hline
\end{tabular}

Angka-angka yang diikuti huruf kecil yang sama pada baris dan huruf besar yang sama pada kolom berbeda tidak nyata menurut uji lanjut DNMRT pada taraf $5 \%$

P $25 \%$, dan pemberian pupuk P $100 \%$ dapat meningkatkan kadar hara $\mathrm{P}$ tanaman sebesar $0,27 \%$.

Hal ini disebabkan pupuk $\mathrm{P}$ yang ditambahkan ke dalam tanah dapat diambil tanaman karena pengikatan $\mathrm{P}$ oleh $\mathrm{Al}$ semakin berkurang sejalan dengan berkurangnya kadar Al-dd tanah (Tabel 2) dan meningkatnya P tersedia tanah (Tabel 3).
Disamping itu dengan berkurangnya kadar Al tanah, akan memberikan peluang bagi akar untuk berkembang lebih baik, sehingga jumlah $\mathrm{P}$ yang dapat diserap menjadi lebih banyak.

\subsection{Berat Biji KA $14 \%$}

Pengaruh pemberian bahan humat dari ekstrak batubara muda (Subbituminus)

Tabel 9. Pengaruh utama pemberian bahan humat dari ekstrak batubara muda (Subbituminus) dan pupuk P terhadap berat biji KA $14 \%$

\begin{tabular}{|c|c|c|c|c|c|}
\hline \multirow[b]{2}{*}{$\begin{array}{c}\text { Takaran Bahan } \\
\text { Humat (ppm) }\end{array}$} & \multicolumn{4}{|c|}{ Takaran Pupuk P (\%Rekomendasi) } & \multirow[t]{2}{*}{ Rata-rata } \\
\hline & 25 & 50 & 75 & 100 & \\
\hline & & ..... & & & \\
\hline 0 & 18,33 & 22,67 & 27,33 & 33,67 & $25,50 \mathrm{D}$ \\
\hline 400 & 36,67 & 37,67 & 42,33 & 46,33 & $40,75 \mathrm{C}$ \\
\hline 800 & 49,33 & 50,00 & 52,33 & 53,00 & $51,17 \mathrm{~B}$ \\
\hline 1200 & 59,00 & 60,33 & 64,67 & 68,67 & $63,17 \mathrm{~A}$ \\
\hline Rata-rata & $40,83 \mathrm{c}$ & $42,67 \mathrm{c}$ & $46,67 \mathrm{~b}$ & $50,42 \mathrm{a}$ & \\
\hline $\mathrm{K}=20,11 \%$ & & & & & \\
\hline
\end{tabular}


dan pupuk P terhadap berat biji KA $14 \%$ disajikan pada Tabel 9. Dari hasil analisis sidik ragam ternyata pengaruh interaksi antara pemberian bahan humat dari ekstrak batubara muda (Subbituminus) dan pupuk $\mathrm{P}$ tidak berbeda nyata terhadap berat biji tanaman jagung. Namun faktor pemberian bahan humat dan pupuk $\mathrm{P}$ pada berbagai takaran berbeda nyata terhadap berat biji KA $14 \%$.

Pada pemberian bahan humat 400 dan 800 ppm pada berbagai takaran pupuk $\mathrm{P}$ dapat meningkatkan berat biji KA $14 \%$ masing-masing sebesar 15,25 dan 25,67 g/pot dibanding tanpa bahan humat. Perlakuan bahan humat 1200 ppm memperlihatkan peningkatan berat biji KA $14 \%$ yang paling tinggi yaitu 37,67 g/pot, Sedangkan pemberian pupuk $\mathrm{P} 25 \%$ memperlihatkan pengaruh yang sama dengan $50 \%$ rekomendasi, tetapi pada takaran pupuk P 75 dan $100 \%$ memperlihatkan berat biji yang lebih tinggi dibanding 25 dan $50 \%$.

Peningkatan bobot pipilan ini disebabkan penambahan bahan humat dan SP-36 mampu memperbaiki sifat kimia tanah dan meningkatkan serapan P tanaman, sehingga pertumbuhan tanaman menjadi lebih baik. Bahan humat mampu berikatan dengan logam oksida hidrous $\mathrm{Fe}$ dan $\mathrm{Al}$ hidroksida sehingga mencegah terjadinya interaksi dengan ion $\mathrm{P}$, dengan kata lain fiksasi $\mathrm{P}$ dapat dihindari dan $\mathrm{P}$ dapat tersedia bagi tanaman (Tan 1998). Hardjowigeno (2003) mengemukakan bahwa, tanaman membutuhkan unsur $\mathrm{P}$ untuk pertumbuhan dan produksinya terutama untuk bunga, buah dan biji, mempercepat pematangan, dan memperbaiki kualitas tanaman. Sutedjo (1994) mengemukakan bahwa, P dapat mempercepat pembungaan, pemasakan buah dan biji serta gabah, dan meningkatkan produksi biji-bijian.

Meskipun kedua faktor perlakuan bahan humat dan SP-36 tidak berinteraksi terhadap tinggi tanaman, kadar hara $\mathrm{P}$ dan bobot biji KA $14 \%$, tetapi masing-masing faktor utama memperlihatkan pengaruhnya. Takaran bahan humat $800 \mathrm{ppm}$ tidak berbeda nyata dengan 1200 ppm dan takaran
SP-36 $75 \%$ tidak berbeda tidak dengan 100 $\%$ rekomendasi, berarti takaran bahan humat $800 \mathrm{ppm}+$ SP-36 75\% merupakan takaran optimum yang dapat digunakan untuk perbaikan sifat kimia tanah Ultisol dan peningkatan produksi tanaman jagung (Zea mays L.).

\section{KESIMPULAN DAN SARAN}

\subsection{Kesimpulan}

1. Tidak ditemukan interaksi antara bahan humat dan SP-36 dalam meningkatkan pertumbuhan, serapan hara dan produksi tanaman jagung (Zea mays L.)

2. Penggunaan bahan humat takaran $800 \mathrm{ppm}$ pada berbagai takaran pupuk $\mathrm{P}$ dapat memperbaiki sifat kimia Ultisol dengan menurunkan kandungan Al-dd sebesar 0,38 me/100 g dan meningkatkan $\mathrm{P}$ tersedia dan KTK tanah masingmasing sebesar 22,16 ppm dan 8,42 me/100 g. serta meningkatkan kadar hara $\mathrm{P}$ dan bobot pipilan kering tanaman jagung masing-masing sebesar $0,10 \quad \%$ dan 25,67 $\mathrm{g}$ dibanding tanpa bahan humat.

3. Penggunaan pupuk $\mathrm{P}$ takaran $50 \%$ rekomendasi pada berbagai takaran bahan humat dapat meningkatkan tinggi dan kadar $\mathrm{P}$ tanaman jagung masing-masing sebesar $26,58 \mathrm{~cm}$ dan $0,11 \%$, sedangkan untuk bobot pipilan kering peningkatan sebesar $5,84 \mathrm{~g} /$ pot terjadi pada takaran pupuk P $75 \%$ dibanding perlakuan $25 \%$ rekomendasi.

\subsection{Saran}

Bahan humat dari ekstrak batubara muda (subbituminus) pada takaran $800 \mathrm{ppm}$ diikuti dengan pemberian SP-36 takaran $75 \%$ rekomendasi merupakan takaran optimum dan dapat digunakan untuk memperbaiki sifat kimia Ultisol dan meningkatkan pertumbuhan, serapan hara dan produksi tanaman jagung (Zea mays L.). 


\section{DAFTAR PUSTAKA}

Ahmad, F. 1988. Effect of clay minerals and clay-humic acid complexes on availability and fixation of phosphates. [Disertasi doctor]. Georgia. University of Georgia. 221 p.

Barnito,N. 2009. Budidaya tanaman jagung. http://nugrohobarnito.blog.plasa.co m/. [17 Juli 2009].

Brady, N.C. dan Weil, R.R. 1999. The nature and properties of soils. Twelfth Edition Prentice Hall. Upper Saddle River, New Jersey. $881 \mathrm{p}$.

Hakim, N., Nyakpa, M.Y., Lubis, A.M., Nugroho, S.G., Diha, M.A., Hong G.B. and Bailey. H.H. 1986. Dasar-dasar ilmu tanah. Lampung. Universitas Lampung. 488 hal.

Hardjowigeno, S. 2003. IImu tanah. Jakarta. Akademi Pressindo. 286 hal.

Havlin, J., Beaton, J.D., Tisdale, S.L. and Nelson, W.L. 1999. Soil fertility and fertilizer an introduction to nutrient management. Sixth Edition. Prentice Hall. Upper Saddle River, New Jersey. 499 p.

Herviyanti, T.B. Prasetyo, T. Agita, A. Alif, 2005. Upaya Pengendalian keracunan Besi $(\mathrm{Fe})$ dengan asam humat dan pengelolaan air untuk meningkatkan produktifitas tanah sawah bukaan baru. Laporan Penelitian hibah bersaing. Oktober 2005.

Herviyanti, T.B. Prasetyo, T. Agita, A.

Alif, 2006. Penyipatan Asam humat dari tanah gambut dan potensinya dalam mengikat besi (Fe) meracun pada tanah sawah bukaan baru. Jurnal Akta Agrosia
Vol. 9, No. 2 Juli- Desember 2006. Hal 94-101.

Herviyanti, T.B. Prasetyo, F. Ahmad, and Darmawan. 2010. The Properties Of Humic Acids Extracted From Several Sources Of Organic Matters And Their Ability To Bind $\mathrm{Fe}^{2+}$ at New Established Ricefield. Journal of Tropical Soils Vol. 15, No. 3. September 2010. P : 237-244.

Huang, P.M. dan Schnitzer, M. 1997. Interaction of soil minerals with natural organics and microbes. SSSA Special Publication Number 17. Soil Science Society of America, Inc. $920 \mathrm{p}$.

Marsi, 1997. Pemanfaatan fraksi humat sebagai alternatif perbaikan sifat kimia dan kesuburan tanah pada lahan pertanian marjinal. Hal 143150. Di dalam: Karakterisasi fraksi humat dan kemampuannya membentuk senyawa kompleks dengan logam. Prosiding Simposium; FP Unsri Indralaya. Seminar Ilmiah Bidang Ilmu Pertanian Dalam Rangka Dies Unsri ke-36.

Rezki, D. 2007. Ekstraksi bahan humat dari batubara muda (Subbituminus) dengan menggunakan 10 jenis pelarut. [Skripsi]. Padang. Fakultas Pertanian. Universitas Andalas. 63 hal.

Rezki, D. 2009. Pengaruh kompos, asam humat dari batubara muda (Subbituminus) dan pupuk buatan terhadap tanaman tomat (Lycopersicum esculenium Mill) pada Oxisol. [Tesis]. Padang. Program Pascasarjana Universitas Andalas.

Sarief, E. S. 1986. Kesuburan dan pemupukan tanah. Bandung. Pustaka Buana. 63 hal.

Stevenson, F. J. 1994. Humus chemistry, genesis, composition, reactions. A 
Wiley-Interscience and Sons New York. 496 p.

Subagyo, H., Suharta, N. dan Siswanto, A.B. 2004. Tanah-tanah pertanian di Indonesia.

http://124.81.86.181/publikasi/p325 2061.pdf. [28 Maret 2009].

Tan, K. H. 2003. Humic matter in soil and environment. New York. Principles and Controversies. Marcel Dekker, Inc. $386 \mathrm{p}$.
Tan, K. H. 2010. Principles of Soil Chemistry Fourth Edition. CRC Press Tailor and Francis Group. Boca Raton. London. New York. $362 \mathrm{p}$.

Team 4 Architects and consulting Engineers bekerjasama dengan fakultas Pertanian Universitas Andalas. 1981. Survei tanah dan Kesesuaian Lahan. Padang. Balittan Sukarami. 153 hal. 